\title{
The Influence of Education Level, Infrastructure and Workplace Environment on Teacher Performance: A Case Study of SMK PGRI Turen Malang
}

\author{
Leonardus Budi Weluk ${ }^{1}$, Rudy Wahyono ${ }^{2}$ and Syaful Arifin ${ }^{3}$ \\ ${ }^{1}$ Student in Master in Management Program, University of Merdeka Malang, Indonesia \\ ${ }^{2,3}$ Faculty Economics and Business \\ University of Merdeka Malang \\ Indonesia
}

\begin{abstract}
This study has several aims: (1) to describe and to test both simultaneously and partially the influence of the level of education, infrastructure and environment on teachers' performance at SMK PGRI Turen, (2) to test the variable that has a dominant influence on teachers' performance at SMK PGRI Turen. There are 42 teachers that are employed as research samples. This analysis technique uses multiple regression analysis as its design. The statistic descriptive results show that the level of education is formed by the teachers' rank of education and teachers' suitability of educational background major. The main thing that supports the level of education, which is the rank of education, is reflected on the level of respondents 'ability to develop students' potential. While the infrastructure facilities are in the form of tables and chairs, books or teaching materials and educational rooms. The main thing that develops infrastructure well is books or teaching materials which can be seen from the use of educational guidebooks during the teaching and learning process by respondents. Furthermore, the workplace environment is formed by lighting, air temperature, and safety at the workplace. The primary thing that can improve the workplace environment is the air temperature in the workplace which can be observed from the air circulation in the teacher's room. On the other hand, teachers' performance is formed by the ability to master teaching material, managing teaching and learning programs, and assessing students' achievement. The principal thing that can improve the teachers' performance is their ability of managing teaching and learning programs which can be seen in the quantity of completed assignments by respondents from their effort of managing learners' learning processes. The level of education, facilities and workplace environment are simultaneously influencing the performance of teachers at SMK PGRI Turen, Therefore, it can be stated that the higher the level of teachers' educational background which is supported by comprehensive workplace facilities, and conducive workplace environment, the better the improvement of the teachers' performance will be. The level of education, facilities and workplace environment partially influence the teachers' performance at SMK PGRI Turen. Thus, it can be concluded that teachers' performance can be improved through an adequate level of teachers' educational background, comprehensive supporting facilities and infrastructure, and a safe and comfortable workplace environment. In short, it can be stated that to improve teachers' performance at SMK PGRI Turen, teachers' level of education, workplace's air temperature as it can be observed from the circulation in the teacher's room are important.
\end{abstract}

Key Words: Level Of Education, Facilities, Workplace Environment, Teacher Performance.

\section{INTRODUCTION}

In an educational institution, teachers/lecturers, students and other factors are inseparable components that contribute to the teaching and learning process, both internally and externally. The implementation of activities which is carried out by an educational institution should pay attention to two main components: students and teachers. They perform interactions called as teaching learning activities. The teaching and learning process can run well if the supporting components of learning process can be fulfilled, for example, the teacher's performance when they presenting learning material.

Currently, there are various problems faced by the world of education, one of them is the inadequate learning process problem. During learning process, not all children are encouraged to develop thinking skills. The learning process is a system. Therefore, to 
achieve the standard process of education quality improvement, it can be started from analyzing each component that share contribution in shaping and influencing the learning process. One of the important components is the teacher component. The teacher component is regarded as highly capable of influencing the educational process. In this chapter, the educational system requires professional teachers, in form of their nature, behavior or even performance.

The results of preliminary research which is conducted on several senior high schools and at the National Education Office of Manado City show that teachers' performance is still low. It can be seen from the lack of teachers' preparation in carrying out their teaching duties. For example, there are still many teachers who do not compile their teaching unit material well. In addition, there are also many teaching subjects which are unequipped with textbooks. This problem is allegedly caused by the school principals' inability to maximize their authority in influencing the increase of teachers' performance. Therefore, if the school principals' authority is used correctly, it is assumed that it will improve the teachers' performance.

In relation to this study, there are several factors that influence the maximum teachers' performance achievement, namely the workplace environment, infrastructure facilities, and teachers 'level of educational background. The teacher's performance can be achieved if the working environment is conducive. Furthermore, it is considered to be approachable once if it is equipped with complete and adequate facilities and infrastructure. This shows that the good performance of the teachers is greatly influenced by the workplace environment. Sehfudin (2011: 11) states the definition of performance, "Performance is a work accomplishment which is a comparison between the work results and the established working standards."

During the implementation of performance, especially the teacher's performance achievement at SMK PGRI Turen, there are several problems occurred on how to manage the class and the learning process within the school environment. Teachers' performance can be said to be less satisfactory due to teachers' assumption that the teaching and learning activities period will be reduced since the time allocation for teaching and learning process is not in accordance with teachers' learning plan. While the Republic of Indonesia's law number 14 of 2005 concerning about teachers and lecturers, states that teachers are professional educators with their main tasks are: educating, teaching, guiding, directing, training, assessing, and evaluating students on: early childhood education, formal education, basic education, and middle education.

However, the teachers at SMK PGRI Turen have an inclination to do their professional duties imperfectly. They tend to leave their job half-finished. This can be seen from the misallocation of teaching program which is not in accordance with the premade teaching and learning programs, and the evaluation of learning outcomes which is not carried out properly. It is mostly related to the working system of school facilities factor.

Meanwhile, the other problems also arise. Teachers are considered to be inactive in motivating their students, for example by digging up more information about students' problems. Next, teachers are less motivated in developing students' knowledge by giving creative learning material. While to improve teachers' performance, teachers should have motivation and abilities in managing the learning process. It can be done by opening the participants' learning knowledge access to make them more creative in developing their learning methods.

This study aims: (1) to describe the influence of teachers' level of educational background, infrastructure and environment on teacher's performance, (2) to examine the partial influence of teachers' level of educational background, facilities and workplace environment on the teachers' performance, (3)to examine the simultaneous influence of teachers' level of educational background, infrastructure and workplace environment on the teachers' performance, and (4) to know which variables (teachers' level of educational background, infrastructure, workplace environment) that have a dominant influence on the teachers' performance at SMK PGRI Turen.

\section{LITERATURE REVIEW}

\subsection{Teachers' Performance}

According to Sehfudin (2011: 11), "Performance is work accomplishment, which is a comparison between the work results and the specified work standards. Furthermore, Rorimpendey (2008: 17) adds that performance is the accumulation of three interrelated elements, namely as competences, efforts, and attitudes of external circumstances. Competences are "raw materials" that someone brings to work, which consist of knowledge, skills, and technical skills. Teachers' job satisfaction can improve student's achievement in carrying out the teaching and learning activities (Dutta and Sahney, 2016)

\subsection{Teachers' Level of Educational Background}

By employing the help of education, someone is prepared to have the provision ofinquiry readiness attitude, recognition, and systematic thinking development methods to solve the arising problems (Sedamaryanti, 2001: 32). Moreover, Sastrohadiwiryo (2002: 62) also states that education is the rank obtained by someone starting from elementary school to high level of education. One's education tend to be limited based on the following factors such as: one's intelligence, financial issue, number of family 
members, and neighborhood. The existence of education institutions with various programs has an important role in the process of obtaining and improving the quality of individual professional abilities. Due to the assistance of education, someone is trained to earn the benefits of inquiry readiness attitude, recognition, and systematic thinking development methods to disentangle the upcoming problems

\subsection{Infrastructure}

The facilities and infrastructure which are based on Minister of Home Affairs Regulation Number 7 of 2006 related to the Standardization of Regional Government Work Facilities and Infrastructures, are as follows:

1) Workplace facilities are facilities which are directly functioned as supporting component on the process of implementing regional government to achieve the established targets, among others: office space, workplace equipment, and government official vehicles.

2) Workplace infrastructure is a facility which is indirectly functioned to support the implementation of government officials' working process, and to improve their performance in accordance with their duties and responsibilities, such as office buildings, government officials' houses and government houses.

\subsection{Workplace Environment}

Saydam (2000: 226) defines the workplace environment as "the whole workplace infrastructure which exists around the employees while they are carrying out their work. It is significant that it can affect the work itself". Furthermore, Lewa and Subono (2005: 235) say that the workplace environment is designed in such a way as to create a working relationship that binds workers with the workplace environment. A pleasant workplace environment can make employees feel at home in completing their work and be able to achieve optimal results. In addition, Sedarmayanti (2009: 21) defines the workplace environment is the entire tooling equipment and materials which are faced by the employees. It is the surrounding environment where an employee works, employee's working method, and employee's working arrangements, both as individual and group.

The behavioral environment consists of components that are related to how well office occupants are connected to each other, and the impact of the office environment on individual behavior (Oswal, 2012). According to Haynes (2008), the physical environment with the productivity of its occupants falls into two main categories: office layout (the open-plan office scellular verses) and office comfort (the matching of office environment with work processes). On the other hand, the behavioral environments represent two main components namely as interaction and disturbance.

\subsection{Hypothesis}

1. The level of teachers' educational background, facilities and workplace environment simultaneously influence the teachers' performance at SMK PGRI Turen.

2. The level of teachers' educational background, facilities and workplace environment partially influence the teacher's performance at SMK PGRI Turen.

3. The level of teachers' educational background has a dominant influence on teacher's performance at SMK PGRI Turen

\section{METHOD}

\subsection{Operational Definition of Variables}

\section{1) Teachers' Performance (Y)}

Teachers' performance was an ability to work or working competence which was shown by a teacher in carrying out his duties as to obtain the optimal work results. It was marked and measured by the following indicators: 1) Arranging the instructional design; 2) Mastering the teaching methods and using them in accordance with the nature of student learning activities; 3) Interacting with students that later on would create high motivation for students since they feel the teaching and learning activities are fun; 4) Mastering materials and using learning resources to generate active learning processes through the development of process skills; 5) Knowing each individual differences to facilitate a thorough learning guidance; and 6) Assessing the process and learning outcomes, providing feedback for students, and designing remedial learning programs. Performance was the final state of work results or work efforts in the form of physical appearance or ideas (Depdikas, 2004: 4)

\section{2) The Level of Teachers' Educational Background (XI)}


The level of teachers' educational background was basically reviewing the levels or ranks of education which were found in formal education. The level of education was a stage of continuing education which was determined based on the level of students' development and the breadth and depth of teaching. (Republic of Indonesia Law No. 20, 2003; in Tarigan, 2006). The indicators / measurements used in measuring the level of education were adopted from (Mahamit, 203) which consisted of: (1) the results of education, (2) characteristics, individuals, (3) knowledge. Thus, it could be stated that the high and low performance result of employees was strongly influenced by the level of education they have. In addition, work experience was also regarded as one of the factors that affect work performance.

\section{3) School Facilities and Infrastructure (X2)}

The school facilities and infrastructure were consisted all of the equipment, materials and furniture both used directly or indirectly during the schools' educational process. The measured aspects included school facilities as it was indicated to the presence of furniture, tools and educational media, books or teaching materials, and supporting equipment. While the school infrastructure included the study group indicator, educational space, and educational rooms. In addition, the infrastructure definition which was in accordance with PP No. 19 of 2005 included school space, classrooms, educational rooms, library, sports venues to support a regular and continuous learning process.

\section{4) Workplace environment (X3)}

The workplace environment was an ecological or physical condition, a social system, a culture around the teachers at the SMK PGRI Turen in carrying out their work. Sedarmayanti (2009: 21) stated that the workplace environment was as follows: the entire tools or equipment and materials faced by employees; the surrounding environment where someone worked; the employees' working method; and the employees' working arrangements both as individuals and as group member.

\subsection{Population and Sampling Techniques}

In this study the population was the teachers at SMK PGRI Turen. There were 42 teachers that were consisted of young and old teachers; male and female teachers also. The sampling technique used was by involving all of the member of population to have an equal opportunity to become the sampling member. This study utilized a non-probability saturated sampling technique (census) since it used all members of the population as samples (Supriyanto and Machfudz, 2010: 88).

\subsection{Data Analysis Technique}

\section{1) Descriptive Analysis}

In this study, the descriptive analysis techniques were used to organize, to present, and to analyze data. For this reason, the descriptive statistics were used by finding the calculated average (mean), and the standard deviation of the variants.

\section{2) Multiple Linear Regression Analysis}

The multiple linear regression analysis was used to determine the influence of independent variables on the dependent variable. It was also used to make predictions on employees' performance:

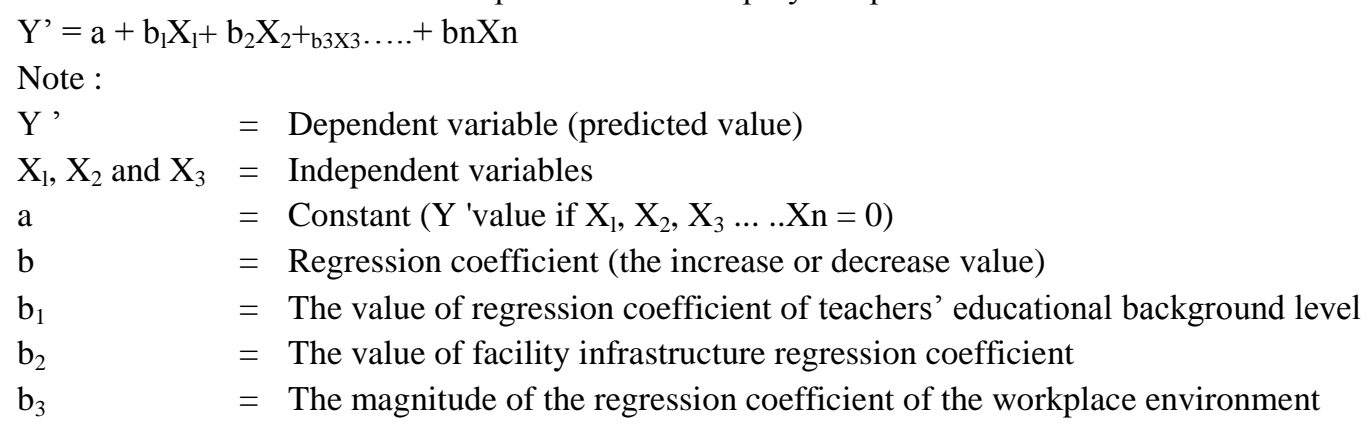

\section{RESEARCH RESULT}

\subsection{Multiple Regression Analysis}

The table below presents the analysis results by processing the data with programmatic computer assistance, SPS 15 for Windows. It can be seen below: 
International Journal of Advances in Scientific Research and Engineering (ijasre), Vol 5 (4), April-2019

Table 1. Recapitulation of Results Results of Analysis I Linear Regression

\begin{tabular}{|l|c|l|l|l|}
\hline \multicolumn{1}{|c|}{ Variables } & \multicolumn{1}{c|}{$\begin{array}{c}\text { Coefficients } \\
\text { Regressive }\end{array}$} & $\mathbf{t}_{\text {count }}$ & Sig. & Note \\
\hline Level of Education $\left(\mathbf{X}_{\mathbf{l}}\right)$ & 0,354 & 4,723 & 0,000 & Significant \\
Infrastructure $\left(\mathbf{X}_{\mathbf{2}}\right)$ & 0,195 & 2,525 & 0,016 & Significant \\
Workplace Environment $\left(\mathbf{X}_{\mathbf{3}}\right)$ & 0,177 & 2,170 & 0,036 & Significant \\
\hline Constant & 0,992 & & \\
$\mathbf{R}$ & 0,766 & & \\
Adjusted $\boldsymbol{R}$ square & 0,554 & & \\
$\mathbf{F}_{\text {count }}$ & 17,974 & & \\
Sig. $\mathbf{F}$ & 0,000 & & \\
$\mathbf{n}$ & 42 & & \\
\hline Bound Variable =Employee's Performance $(\mathrm{Y})$ & \\
\hline F table $=\mathbf{2 , 8 5}$ \\
$\mathbf{t}$ table $=\mathbf{2 , 0 2 1}$
\end{tabular}

Based on the recapitulation table, the multiple regression equation is obtained as follows:

$\mathrm{Y}=0,992+0,354 \mathrm{X} 1+0,195 \mathrm{X} 2+0,177 \mathrm{X} 3$

The detail explanation for the above equations is as follows:

$\alpha=0.992$ was a constant which meant that if all of the independent variables of the level of teachers' educational background $(\mathrm{Xl})$, infrastructure (X2), and workplace environment (X3) were 0 , then the variable of teacher performance was 0.992 .

$\beta 1=0.354$ was the magnitude of independent variable regression coefficient of the teachers' educational background level (Xl).The regression coefficient result was positive. It indicated that the level of education had a direct influence on teachers' performance. It meant that the higher the level of teachers' educational background, the higher the teachers' performance increasement would be by assuming that the infrastructure facilities (X2) and the workplace environment (X3) value sare fixed. While the influence of teachers' educational background levelon teachers' performance was 0.354

$\beta 2=0.195$ was the magnitude of the regression coefficient of infrastructure facilities independent variable (X2).The regression coefficient had a positive sign indicating that infrastructure had a direct influence on teachers' performance. It meant a better infrastructure would lead to therise of teachers' performance by assuming that the variable of teachers' educational background level (Xl) and workplace environment (X3) valuesare fixed. While the influence of facilities on teacher performance was 0.195 .

$\beta 3=0.177$ was the magnitude of the independent variable regression coefficient of workplace environment (X3). The regression coefficient had a positive sign. It could be inferred that the workplace environment had a direct influence on teachers' performance. Thus, a better infrastructure would cause teachers' performance improvement by assuming that teachers' educational background level (X1) and the means of the infrastructure (X2) were fixed. While the influence of the workplace environment on teacher performance was 0.177 .

The multiple correlation coefficient (R) was 0.766. It signified a strong relationship between teachers' educational background level (X1), infrastructure (X2), and workplace environment (X3) together with teachers' performance (Y). Furthermore, the coefficient of determination (Adjusted $\mathrm{R}$ square) was 0.554 . This coefficient of determination meant that the level of teachers' educational background (X1), infrastructure (X2), and workplace environment (X3) together could contribute to teachers' performance by $55.4 \%$, while the remaining $22.6 \%$ was caused by other variables that were not included in this study.

\subsection{Hypothesis testing}

\section{a. First Hypothesis Testing}

Researchers tested the first hypothesis by using the $\mathrm{F}$ test. From the results of multiple regression calculation analysis with SPSS, the obtained $\mathrm{F}_{\text {count }}$ was 7.974 , while $\mathrm{n} \mathrm{F}_{\text {table }}$ was at $\mathrm{a}=5 \%$, $\mathrm{df}=3$, and $\mathrm{df} 2=38$ of 2.85 ; this meant that $\mathrm{F}_{\text {count }}>\mathrm{F}_{\text {table }}$ $(17,974)>2.85)$ while the probability value was smaller than $\mathrm{a}=0.05(0.014<0.05)$.Then, Ho was rejected and Ha was accepted which pointed at the independent variables: teachers' educational background level, facilities and workplace environments. All of the variables had a simultaneously significant influence on teachers' performance. Thus, the first hypothesis was statistically acceptable or tested. 
International Journal of Advances in Scientific Research and Engineering (ijasre), Vol 5 (4), April-2019

\section{b. Second Hypothesis Testing}

To test the second hypothesis, researchers utilized the $\mathrm{t}$ test. The $\mathrm{t}$ test was used to test whether each independent variable (teachers' educational background level, infrastructure and workplace environment) partially had a significant influence on teachers' performance. The result was obtained by comparing between $\mathrm{t}_{\text {count }}$ and $\mathrm{t}$ table.

Table 2. the Comparison of $t_{\text {count }}$ and $t$ table $a=5 \%$

\begin{tabular}{|l|l|l|l|l|}
\hline \multicolumn{1}{|c|}{ Variabel } & \multicolumn{1}{|c|}{$\mathbf{t}_{\text {hitung }}$} & \multicolumn{1}{c|}{$\mathbf{t}_{\text {tabel }}$} & \multicolumn{1}{c|}{ Sig. } & \multicolumn{1}{c|}{ Note } \\
\hline Level of Education $\left(\mathrm{X}_{1}\right)$ & 4,723 & 2,021 & 0,000 & Significant \\
\hline Infrastructure $\left(\mathrm{X}_{2}\right)$ & 2,525 & 2,021 & 0,016 & Significant \\
\hline Workplace Environment $\left(\mathrm{X}_{3}\right)$ & 2,170 & 2,021 & 0,036 & Significant \\
\hline
\end{tabular}

The explanation for table 2 is as follows:

1) Variable education level (Xl)

The obtained results for the regression analysis was the value of $t_{\text {count }}=4.723$ while the value of $t_{\text {table }}=2.021$. Therefore, the $t_{\text {count }}>t_{\text {table }}$ or it could be stated that the significance value was $0.000<0.05$. Thus, it was either Ho was rejected or Ha was accepted, and it had been proven that the level of teachers' educational background variable (Xl) had a significant influence on teachers' performance $(\mathrm{Y})$.

2) Infrastructure variables (X2)

The obtained results for the regression analysis was the value of $t_{\text {count }}=2.525$ while the value of t table $=2.021$. Therefore, the $t_{\text {count }}>t_{\text {table }}$ or it could be inferred that the significance value was $0.016<0.05$. Thus, it was either Ho was rejected or Ha was accepted, and it had been proven that infrastructure facilities (X2) had a significant influence on teachers' performance (Y).

3) Workplace environment variables (X3)

The obtained result of the regression analysis was the value of $t_{\text {count }}=2,170$ while the value of $t$ table $=2.021$. Therefore, $t_{\text {count }}>$ $\mathrm{t}$ table or it could be concluded that the significance value $0.036<0.05$. Thus, it was either, Ho was rejected or Ha was accepted, and it had been proven that work place environment variables (X3) had a significant influence on teachers' performance (Y). Based on the result of the $t$ test, it could be proven that the level of teachers' educational background, infrastructure and workplace environment partially had a significant influence on teacher performance (Y). Thus, both were statistically acceptable or tested.

\section{c. Third Hypothesis Testing}

The third hypothesis was tested using the t test and the large regression coefficient. Based on the obtained test results, it could be concluded that the level of teacher's educational background, facilities and workplace environment had a significant influence on teachers' performance. From the results of multiple regression analysis, it can be confirmed that the largest regression coefficient was teachers' educational background level $=0.544$. Therefore, the level of teachers' educational background was the dominant variable on teachers' performance. Thus, both were statistically acceptable or tested.

\section{DISCUSSION}

\subsection{The Description of Education, Infrastructure, Workplace Environment and Teachers' Performance Levels}

The level of teachers' educational background was formed by teachers' level of education and their suitability majors. The main thing that supported the level of teachers' educational background, was reflected on the level of respondents 'ability to develop students' potential. It was in accordance with Sastrohadiwiryo (2002: 62) statement, he said that education was the level obtained by someone starting from elementary school to high level of education.

The infrastructure facilities were in the form of tables and chairs, books or teaching materials, and educational rooms. The main thing that built infrastructure was books or teaching materials reflected from the way respondents using educational guidebooks during teaching and learning process. The standard facilities and infrastructure were the national education standards. It was related to the minimum criteria about the followings: learning rooms, sport venues, worship places, library, laboratories, playgrounds, recreation areas. Those things were needed to support the learning process including the use of information and communication technology. Educational infrastructure was one of the supporting factors for teachers. We could make a 
comparison between teachers who had adequate facilities and infrastructure with teachers who experienced insufficient infrastructure. Teachers who were equipped with adequate infrastructure showed a better performance than teachers who did not have adequate infrastructure. The infrastructure included schools' space, classrooms, educational rooms, library spaces, and sports venues to support regular and continuous learning process (PP No. 19 of 2005).

Meanwhile, the workplace environment consisted of workplace, air temperature, and security in the workplace. The primary thing that could improve the workplace environment was the air temperature at the workplace. It was revealed from the air circulation within teacher's room. A conducive workplace environment provided a sense of security and allowed teachers to work optimally. The workplace environment could affect the teachers' emotions. If teachers enjoyed the workplace environment where they worked, then they would feel at home at their work place. Teachers would do their activities influenceively and optimally. Thus, the teacher's work performance would be also high. It was in accordance with opinion Saydam (2000: 226), he defined the workplace environment as "the entire work infrastructure around employees who were carrying out their work that can affect the work itself."

Teachers' performance comprised mastering the material to be taught, managing teaching and learning programs and assessing student achievement. The foremost thing that could improve teachers' performance was teachers' ability to manage teaching and learning. It could be observed from the number of completed work which was portrayed by respondents' ability in managing students' learning process. It was in line with statement Sehfudin (2011: 11), he stated that "Performance was a work accomplishment, which was a comparison between the work result and the established work standard.

\subsection{The Impact of Teachers' Educational Background Level on Teachers' Performance}

The level of teachers' educational background influences teachers' performance and it was a variable that had the dominant influence on teachers' performance. Thus, the higher the level of teachers' education, the better will be the teachers' performance. The level of education reflected the intelligence and skills owned by the teachers. The higher the level of teachers' educational background, the greater the likelihood that teachers would hold higher administrative position. This was because the higher level of teachers' educational carried the higher level of competence. The main purpose of education was basically to improve teachers' capabilities that had direct impact on increasing teachers' performance. Providing education for teachers could also increase their knowledge and skills. It would help teachers to carry out their work more efficiently, developing teachers' skills, and teachers' attitudes. It was in line with statement Hariandja (2002: 69) that the level of teachers' educational background could increase school's competitiveness and improve schools' performance. The level of teachers' educational backgroundwas the academic qualifications that teachers had obtained from formal education, such as: diploma, bachelor, master, specialist, and doctoral degree held by accountable universities (academy, polytechnics, specialized colleges, tertiary institutions)which were proven by the existence of teachers' diploma certificates. In an educational process, participants were provided with academic abilities, skills and attitudes so that it could later be used after completing education. Thus, the higher the level of teachers' educational background, the better the quality of the teachers' performance would be. If a teacher had suitable educational background as his field of work, then his performance would also be good. The results of this study were in line with opinion Handayani (2005) which stated that the level of teachers' educational background affected teachers' performance.

\subsection{The influence of infrastructure facilities on Teachers' Performance (PPp)}

The infrastructure facilities affected teachers' performance, which mean ta complete school's infrastructure could improve teachers' performance. It was one of the most vital objects supporting the achievement of educational goals in the learning and teaching process. Teachers' and institutions/schools' ability to fulfill educational facilities and infrastructure would greatly influence the teaching and learning process at schools. In organizing the learning process, teacher certainly required infrastructure that could support its performance so that learning could take place attractively. With the support of adequate learning infrastructure facilities, teachers not only deliver material verbally, but also by writing and modeling in accordance with the infrastructure prepared by the teacher.

Teachers required adequate learning infrastructure in supporting teaching and learning activities. In addition to the teacher's ability to organize learning activities, the support of learning infrastructure was also very important in helping teachers. The more well-equipped and adequate learning facilities a school had, the easier teachers would be in carrying out their duties as educational staff. Similarly, the atmosphere during learning activities was also contributed on teachers' performance. Learning tools should be developed in order to support the teaching and learning process. The infrastructure was highly important during teaching and learning activities since students, teachers and schools were directly related to one another. Students would likely receive more help by the support of learning infrastructure because not all students had a good level of intelligence. Therefore, the use of learning infrastructure would help students, especially those who had weaknesses to participate within learning activities. On the 
other hand, for teachers, they would gain more help by the support of infrastructure facilities. Learning activities could be more varied, interesting and meaningful. The school was obliged as the most responsible party for the management of all activities at school. In addition to provide adequate learning infrastructures, school was also obliged to preserve and to maintain the condition of its own infrastructures. The results of this study were in accordance with Handayani (2005) and Gagarin (2000) opinion which stated that infrastructure had an influence on teachers' performance.

\subsection{The Influence of Workplace Environment on Teachers' Performance}

The workplace environment influenced teachers' performance. It implied that the better the workplace environment at school, the better the teachers' performance would be. Teachers would be able to carry out their activities well to achieve an optimal result if they were supported with a good environmental condition. A healthy, clean, comfortable and pleasant workplace environment could leverage teachers' performance. Teachers who worked in good working conditions would end up with high productivity. Therefore, school should always pay attention towards workplace environment conditions for its teachers, such as lighting, air temperature and safety. Thus, school would gain great benefits which were in accordance with school's objectives. The state of the workplace environment determined how smooth a job could be exercised. If the workplace environment was comfortable, teachers would be lightheartedly carrying out their work. Moreover, it could reduce teachers' weariness which was hopefully, later on, could lead into the betterment of teachers' performance. A sense of comfort and pleasure would psychologically affect someone to be more active, diligent and enthusiastic in completing his work. If the workplace situation or workplace environment was uncomfortable, there would be a decrease of achievement on teachers' performance. Thus, the leader was expected to always strive for the betterment of school's facilities and infrastructure to give comfortable environment for teachers when they worked. In addition, the leader was expected to always create a harmonious relationship with the teacher. It was considered to be a way to provide an assurance or the teachers. They would feel that they were well treated in a workplace environment. The results of this study were in line with Handayani (2005) and Firmansyah (2008) findings which stated that the workplace environment had an influence on performance.

\section{CONCLUSION}

1) The descriptive results of statistics show that the level of teachers' educational background is formed by the rank of teachers' education and their educational majors' suitability. Furthermore, the principal thing that supports the level of teachers' educational background, was teachers' rank of education. It can be seen from the level of respondents' ability to develop students' potential. While, the infrastructure facilities are consisted of tables and chairs, books or teaching materials, and educational spaces. The primary thing that develops infrastructure is books or teaching materials. This fact can be observed form the way respondents using educational guidebooks in the teaching and learning process. Last, the workplace environment is related to lighting, air temperature, and safety at workplace. The work place environment can get better if the air temperature at teacher's room is well managed.

2) The level of teachers' educational background, facilities and workplace environment simultaneously influence teachers' performance at SMK PGRI Turen. It means that the higher the level of teachers' educational background, the better the teachers' performance will be. Of course, it has to be supported by an adequate workplace infrastructure, and be supported also by a conducive workplace environment

3) The level of teachers' educational background, facilities and workplace environment partially influences the teachers' performance at SMK PGRI Turen. This shows that teacher performance can be expand through adequate teachers' education levels, adeaquate supporting facilities and infrastructure, and a safe and comfortable workplace environment.

4) Teachers' level of educational background has a dominant influence on teachers' performance at SMK PGRI Turen. This shows that the main thing that can improve teachers' performance at SMK PGRI Turen is their level of educational background. In addition to the well management of air temperature in the teacher's room.

\section{SUGGESTION}

Concerning with the previously discussed matters, researchers suggest the following things:

1) To improve teacher performance, teachers should be given teaching assignments which was in accordance with teachers' educational background department/major.

2) School should ensure that the tables and chairs are in good condition by conducting periodic maintenance.

3) School should create a comfortable workplace environment to facilitate a well running learning process.

4) Future researchers are expected to develop subsequent research by using other independent variables, such as teachers' discipline and teachers' motivation influences on teachers' performance. 


\section{REFERENCES}

1. Dutta, dan Sahney. 2016. School Leadership and Its Impact on Student Achievement: The Mediating Role of School Climate and Teacher Job Satisfaction", International Journal of Educational Management, Vol. 30 Issue: 6: 941-958.

2. Firmansyah, Farid. 2008. Pengaruh Lingkungan Kerja, Kompensasi dan Kepemimpinan terhadap Kepuasan Kerja Guru dan Karyawan di SMA Wachid Hasyim Surabaya. Tadris Vol 3 No 1.

3. Gagarin. 2010. Pengaruh Sarana dan Prasarana Sekolah terhadap Kinerja Guru di Kabupaten Alor Nusa Tenggara Timur. Makassar: Universitas Hasanuddin.

4. Handayani. 20005. Pengaruh Tingkat Pendidikan, Sarana Prasarana terhadap Kinerja Guru, Surakarta: Universitas Muhammadiah Surakarta.

5. Hariandja, Marihot Tua Efendi. 2002. Manajemen Sumber Daya Manusia, Grasindo, Jakarta.

6. Haynes, 2008. An Evaluation of the Impact of the Office Environment on Productivity. Journal of Facilities.

7. Lewa, K., Iip, Idham, Eka dan Subowo, 2005, "Pengaruh Kepemimpinan, Lingkungan Kerja Fisik dan Kompensasi Terhadap Kinerja Karyawan di PT. Pertamina (Persero) Daerah Operasi Hulu Jawa Bagian Barat Cirebon.” Jurnal SINERGI:Kajian Bisnis dan Manajemen Edisi Khusus on Human Resources.

8. Oswal, 2012. The Effect of Working Environment on Workers Performance: The Case of Reproductive and Child Health Care Providers in Tarime District. Jornal of management.

9. Peraturan Menteri Dalam Negeri No. 7 Tahun 2006 tentang Standarisasi Sarana dan Prasarana Kerja Pemerintahan Daerah.

10. Rorimpandey. 2008, Kinerja Guru Sekolah Dasar di Kabupaten Minahasa Selatan. Tesis. Magister Universitas Negeri Yogyakarta.

11. Sastrohadiwiryo, B. Siswanto. 2002. Manajemen Tenaga Kerja Indonesia Pendekatan Administrasi dan Operasional. Jakarta : Bumi Aksara.

12. Saydam, Gaouzali. 2000. Manajemen Sumber Daya Manusia (Suatu Pendekatan Mikro). Jakarta: Djambatan.

13. Sedarmayanti. 2001. Metodologi Penelitian., Bandung : Mandar Maju.

14. Sedarmayanti. 2009. Sumber Daya Manusia dan Produktivitas Kerja. Bandung: CV. Mandar Maju.

15. Sehfudin. 2011. Pengaruh Gaya Kepemimpinan,Komunikasi Organisasi Dan Motivasi Kerja Terhadap Kinerja Karyawan (Studi Pada PT Bank Tabungan Pensiunan Nasional Cabang Semarang).

16. Supriyanto, Achmad Sani. dan Masyhuri Machfudz. 2010. Metodologi Riset: Manajemen Sumberdaya Manusia. Malang: UIN-Maliki Press.

17. Tarigan, Daitin. 2006. Pembelajaran Matematika Realistik. Jakarta: Departemen Pendidikan Nasional Direktorat Jendral Pendidikan Tinggi.

18. Undang-Undang Republik Indonesia No. 14 TAHUN 2005 tentang Guru dan Dosen. 